NBER WORKING PAPER SERIES

\title{
PUBLIC HEALTH INSURANCE AND PRIVATE SAVINGS
}

\author{
Jonathan Gruber \\ Aaron Yelowitz
}

Working Paper 6041

\author{
NATIONAL BUREAU OF ECONOMIC RESEARCH \\ 1050 Massachusetts Avenue \\ Cambridge, MA 02138 \\ May 1997
}

\begin{abstract}
We are grateful to Peter Diamond, Jonathan Skinner, and seminar participants at Boston College for helpful comments, and to the National Institute on Aging (Gruber and Yelowitz) and the National Science Foundation (Gruber) for financial support administered by the National Bureau of Economic Research. This paper is part of NBER's research programs in Aging, Children, Health Care and Public Economics. Any opinions expressed are those of the authors and not those of the National Bureau of Economic Research.

(C) 1997 by Jonathan Gruber and Aaron Yelowitz. All rights reserved. Short sections of text, not to exceed two paragraphs, may be quoted without explicit permission provided that full credit, including $(\mathcal{C}$ notice, is given to the source.
\end{abstract}


Public Health Insurance and Private Savings

Jonathan Gruber and Aaron Yelowitz

NBER Working Paper No. 6041

May 1997

JEL Nos. H51, I18, E21

Aging, Children, Health Care and Public Economics

\begin{abstract}
$\underline{\text { ABSTRACT }}$
Recent theoretical work suggests that means and asset-tested social insurance programs can explain the low savings of lower income households in the U.S. We assess the validity of this hypothesis by investigating the effect of Medicaid, the health insurance prograrn for low income women and children, on savings behavior. We do so using data on asset holdings from the Survey of Income and Program Participation, and on consumption from the Consumer Expenditure Survey, matched to information on the eligibility of each household for Medicaid. Exogenous variation in Medicaid eligibility is provided by the dramatic expansion of this program over the 1984-1993 period. We document that Medicaid eligibility has a sizeable and significant negative effect on wealth holdings; we estimate that in 1993 the Medicaid program lowered wealth holdings by $17.7 \%$ among the eligible population. We confirm this finding by showing a strong positive association between Medicaid eligibility and consumption expenditures; in 1993, the program raised consumption expenditures among eligibles by $5.2 \%$. We also exploit the fact that asset testing was phased out by the Medicaid program over this period to document that these Medicaid effects are much stronger in the presence of an asset test, confirming the importance of asset testing for household savings decisions.
\end{abstract}

Jonathan Gruber

Department of Economics

E52-355

Massachusetts Institute of Technology

Cambridge, MA 02139

and NBER

gruberj@mit.edu
Aaron Yelowitz

Department of Economics

405 Hilgard Avenue

University of California

Los Angeles, CA 90024

and NBER

yelowitz@nber.org 
One of the most striking regularities about savings behavior in the U.S. is the skewed nature of wealth holdings. For example, the median asset/income ratio for households headed by an 35-44 year old high school dropout is one-tenth that of households headed by an 35-44 year old college graduate: ${ }^{1}$ In a provocative recent article, Hubbard, Skinner, and Zeldes (1995) (hereafter, HSZ) suggest that one explanation for this skewness is the structure of means-tested social insurance programs in the U.S. They develop a simulation model of precautionary savings with uncertainty concerning earnings, uninsured necessary medical expenditures, and lifespan, and include a minimum level of consumption provided by a means-tested social insurance program. They show that social insurance can significantly reduce savings through two mechanisms: by mitigating the need for precautionary savings through the provision of a welfare safety net for consumption, and by taxing away individual savings through means-testing of assets to qualify for government assistance. These effects are largest for the low income households for whom this safety net (and asset testing) is most relevant, resulting in skewed asset holdings.

While compelling in theory, the practical importance of social insurance programs for savings behavior is not clear. This explanation for low savings at the bottom of the income distribution requires not only that low income households are aware of the savings disincentives inherent in their social insurance entitlements, but that they incorporate these disincentives into their consumption and savings decisions. Unfortunately, there is little empirical evidence on the response of households to means-tested, asset-tested social insurance programs which can support or refute these contentions.

The purpose of this paper is to provide such evidence. We do so by focusing on the savings effects of the fastest growing social insurance program in the U.S.: the Medicaid program, which provides health insurance for low income individuals. Medicaid expenditure grew by over 500

\footnotetext{
${ }^{1}$ From authors' tabulations of the SIPP data described below; assets is total household net worth.
} 
percent from 1984 to 1994 , roughly tripling as a share of total federal spending. ${ }^{2}$ By providing first-dollar coverage of medical expenditures for qualifying individuals, Medicaid substantially lowers the expenditure risk facing uninsured families. In addition, the program lowers the risk facing some insured families: those facing large copayments or deductibles under their private plan, who as a result drop that plan and join the Medicaid program. Moreover, along with means-testing, Medicaid has also traditionally incorporated asset tests into its eligibility determination process. Thus, if social insurance is playing the role suggested by the HSZ model, savings and consumption should respond to programs like Medicaid.

Our paper studies the relationship between Medicaid and savings/consumption behavior, using the exogenous assignment of insurance to the low income population that occurred through the Medicaid expansions of the late 1980s and early 1990s. The Medicaid program substantially eased its eligibility criteria over this period, first by state fiat, and later by federal mandate. The expansion occurred at a differential pace across the states, and even within states through differential age cutoffs for the eligibility of children. This quasi-randomization of insurance coverage allows us to assess the effect of providing free health insurance on savings behavior while avoiding issues of selection in who chooses public insurance coverage. Moreover, throughout this period states were removing their asset tests for program qualification. This allows us to quantify the interaction between means testing and asset testing of eligibility for this program.

To carry out this test, we use data from two sources. The first is the Survey of Income and Program Participation (SIPP), the largest nationally representative survey with annual data on the asset holdings of the U.S. population. The second is the Consumer Expenditure Survey (CEX), the only U.S. database with annual data on total family consumption levels. We construct a household-

\footnotetext{
${ }^{2}$ Gruber (1996).
} 
specific valuation of the Medicaid expansions, and match this measure to the SIPP data on household asset holdings and the CEX data on consumption. We find a highly significant, negative relationship between the generosity of a family's public insurance entitlement and that family's asset holdings. We confirm this finding by showing that there is a strong positive effect of Medicaid entitlement on consumption spending in the Consumer Expenditure Survey (CEX). And, in both cases, we find that the effect of Medicaid eligibility is much stronger in the presence of an asset test. The robustness of our finding across two very different sources of data confirms that Medicaid is an important determinant of the savings decisions of eligible households.

Our paper proceeds as follows. In Part I, we provide some theoretical background, review previous evidence on social insurance and savings, and describe the Medicaid expansions that form the backbone of our empirical approach. In Part II, we discuss the data and estimation strategy. Part III presents our SIPP results for asset accumulation, and our CEX results for consumption. Part IV concludes.

\section{Part I: Background}

\section{The Medicaid Expansions}

The key variation in public insurance availability for our analysis comes from the dramatic expansion of the Medicaid program over the late 1980s and early 1990s. Medicaid coverage of medical expenses was traditionally limited primarily to very low income single female-headed families who received cash welfare under the Aid to Families with Dependent Children (AFDC) program. There were also a number of other programs, offered at the discretion of the states, that extended coverage to other groups such as married couples where the head was unemployed (AFDCUP program) and children in two-parent families who met the income criteria for eligibility (the 
Ribicoff Children program). While these options relaxed the family structure restrictions for the program in some cases, eligibility was still restricted only to very poor persons.

Beginning in 1984, however, the program expanded eligibility for all children, and for pregnant women; that is, for women, these expansions applied to the expenses of pregnancy only. From 1984-1987, there were additional increases in Medicaid eligibility for families who had similar financial circumstances to AFDC families, but who did not meet the eligibility criterion due to family structure (similar to the state options noted above). From 1987 onwards, there were substantial increases in the income cutoff for Medicaid eligibility, for children and pregnant women in all family structures. By 1990, states were required to cover all pregnant women and children under the age of 6 up to 133 percent of poverty (independent of family composition), and were allowed to expand coverage up to 185 percent of poverty. ${ }^{3}$ In addition, children born after September 30, 1983, were mandatorily covered up to 100 percent of poverty (once again independent of family composition). These expansions are described in more detail in Currie and Gruber (1996a,b). Nationally, the expansions had an enormous impact on the Medicaid eligibility of children and pregnant women; by 1992, roughly one-third of children in the U.S. were eligible for Medicaid for coverage of their medical expenses, and almost one-half of women were eligible for the expenses of pregnancy.

While most of the legislative action over this period was at the federal level, there was tremendous heterogeneity in the impacts of Medicaid policy changes across the states. States initially had different qualification limits through AFDC and other optional programs, so that the uniform national expansions had differential impacts depending on ex ante state standards. In addition, states took up the new eligibility options at different rates, providing variation in the timing of the

\footnotetext{
${ }^{3} \mathrm{~A}$ number of states have even expanded coverage above 185 percent of poverty for pregnant women and infants, using state funds only with no federal match.
} 
expansions as well as the ultimate size of their effects. There was also variation within states in the eligibility of children of different ages for the Medicaid expansions, due to different age thresholds in the laws.

This legislative variation is illustrated in Table 1, updated from Yelowitz (1995). This Table shows the age and percent of poverty cutoffs for expansions to the youngest group of children in each state at four different points in time. ${ }^{4}$ In January, 1988, only some states had expanded eligibility, and the income and age cutoffs varied. By December, 1989, all states had some expansion in place since Federal law mandated coverage of infants up to 75 percent of the poverty line; but some states had expanded coverage up to age 7 or 8 , and coverage ranged as high as 185 percent of the poverty line. By December, 1991, state policies were more uniform as the most restrictive federal mandates had taken place, but some variation in poverty cutoffs remained. In the subsequent years, several states expanded the age limits even further, using state only f̣unds.

A key feature of these expansions is that the population that was affected was not just the uninsured, but also those with private insurance. Indeed, as Cutler and Gruber (1996a) note, twothirds of those made eligible for the Medicaid expansions were already covered by private insurance before becoming eligible. This raises the prospect that the expansion of the Medicaid program may have "crowded out" private insurance purchases, a claim which has found empirical support in a series of papers over the past two years (Cutler and Gruber, 1996a; Currie, 1995; Rask and Rask, 1995). ${ }^{5}$ Cutler and Gruber, using a methodology similar to ours, estimate that one person lost private insurance coverage for every two persons joining the Medicaid program. But no previous

\footnotetext{
${ }^{4}$ There were additional expansions for older groups of children as well, but this table usefully illustrates the variation in eligibility that we exploit in our estimation.

${ }^{5}$ For a dissent, using a very different methodology, see Dubay and Kenney (1996); see also the response in Cutler and Gruber (1997).
} 
studies have explored another potentially interesting avenue of "crowdout": reduced asset accumulation in response to increases in Medicaid eligibility.

\section{Theoretical Background}

There are three channels through which increased Medicaid generosity might affect savings and consumption decisions: precautionary accumulation, redistribution, and asset testing. In this section, we provide an overview of the expected effect of Medicaid on savings and consumption through each of these three channels.

First, by reducing medical expenditure risk for eligible families, the Medicaid program lowers their need for precautionary savings. This will raise consumption and lower wealth holdings. ${ }^{6}$ This point is explicitly demonstrated by Kotlikoff (1988). He presents simulations of a life-cycle model with uncertainty which demonstrate that asset accumulation will be much lower. in an economy with public insurance available than in one where individuals self-insure their medical expenses through savings. ${ }^{7}$

\footnotetext{
${ }^{6}$ In fact, over the entire lifetime, the consumption effect is ambiguous. Assuming no bequest motive, individuals will eventually desire to run down their stock of precautionary savings against medical risk as they near the end of life and the total stock of future risk shrinks. Thus, reduced income risk will raise consumption today, but may lower it close to the end of life. In our empirical work, however, we focus on families with no members over age 64 , so that for this younger sample there should be only negative effects of medical risk on consumption, and thus positive effects of Medicaid eligibility increases.

${ }^{7}$ Modelling the precautionary motive for wealth accumulation has a long tradition, dating at least back to Fisher (1956) and Friedman (1957); see Deaton (1992) and Browning and Lusardi (1996) for reviews of recent developments. A natural implication of precautionary savings models is that social insurance programs, by reducing income or expenditure risk, will reduce asset accumulation. This point has been made in the context of the Social Security program by Sheshinski and Weiss (1981), Abel (1985), Kotlikoff, Shoven, and Spivak (1987), and Hubbard and Judd (1987), and in the context of the unemployment insurance program by Hansen and Imrohoroglu (1992) and Engen and Gruber (1995). A more general treatment of social insurance and precautionary savings was introduced by HSZ, who consider the distributional impacts of social insurance as well as its effect
} 
Of course, this effect will only operate to the extent that eligible (low income) families are using savings as self-insurance against medical risk. Medical risk seems an unlikely candidate for self-insurance, as opposed to market insurance, since spending is extremely variable. In fact, however, self-insurance of medical expenses may be a reasonable option for many families. Unless a family has access to a large group through which to purchase insurance, health insurance can be prohibitively expensive. The loading factor on insurance purchases by the very smallest groups (firms with less than 5 employees) is over 40 percent higher than that on very large groups (more than 10,000 employees), and the loading factor for individual insurance is even higher (Congressional Research Service, 1988). And individually purchased insurance often comes with a number of restrictions on services covered and coverage of pre-existing conditions which lower its value further (Gruber and Madrian, 1994). Moreover, uninsured families have implicit re-insurance for large medical expenditures, through the provision of free care by hospitals, particularly public hospitals; such "uncompensated care" amounted to over $\$ 15$ billion in 1989 (Gruber, 1994b). Thus, it is plausible that there may be precautionary savings as self-insurance among the uninsured, and that Medicaid might lower this savings.

There may also be some self-insurance of medical spending risk among the insured who (potentially) move on to the Medicaid program as well. The average privately insured family pays about one-third of their medical costs (Cutler and Gruber, 1996a). These costs are to some extent variable (up to plan out-of-pocket maxima), so that families who do not typically hit the out of pocket maximum may be saving as insurance against a particularly expensive year of medical spending. In contrast, Medicaid provides first dollar coverage of virtually all medical expenses. Thus, when a privately insured family moves onto Medicaid, their (limited) precautionary savings may be

on average savings, and who incorporate the role of asset testing. 
reduced as well.

This negative effect on wealth holdings is offset, however, by the second effect: Medicaid is explicitly redistributive, and as such increases the resources of persons who become eligible for the program. For those who were previously uninsured, this increase occurs through reducing their expected medical outlays. For those who have private insurance, but chose to drop it in order to sign up for the Medicaid program, there is a reduction in expected outlays for both out of pocket spending and insurance payments. ${ }^{8}$. This redistributive transfer is transitory; it only lasts as long as the family is eligible for Medicaid, on both income and demographic grounds. Thus, to the extent that families are operating in a forward looking life-cycle framework, the transfer will be saved, and spread over future periods where there is higher out of pocket medical spending risk. Under this model, then, the redistributive effect will partially offset the precautionary savings reduction.

On the other hand, to the extent that families are not perfectly forward looking, some of this transfer will be spent today. In this case, the increase in savings from this transfer will be smaller; in the limit, there may be no change in savings, and it will all be spent today. Thus, the net effect of expanded Medicaid on wealth accumulation is ambiguous, and depends on the extent to which this redistributive transfer is saved. ${ }^{9}$ On the other hand, the effect on consumption is unambiguous: it will increase through reduced precautionary accumulation, as well as (to some extent) through increased spending in response to this redistributive transfer.

${ }^{8}$ These insurance payments may have been explicit, through individual insurance purchase or employer premium-sharing arrangements, or implicit, through reduced wages for those provided insurance by their employers. Evidence for such implicit payments is presented in Gruber (1994a), Gruber and Krueger (1991), and Sheiner (1996).

${ }^{9}$ That is, consider the case where individuals are risk neutral (so that there is no precautionary savings) but forward looking. Then a risk-decreasing transfer such as Medicaid will raise wealth holdings. 
The third and final channel is one that is highlighted by HSZ: asset testing. Traditionally, eligibility for AFDC (and hence Medicaid) was conditioned on asset holdings of less than $\$ 1000$ per family. ${ }^{10}$ As part of the legislation that allowed states to expand their income cutoffs for Medicaid eligibility, the federal government also authorized states to remove their asset tests for determining eligibility. States were quick to drop asset testing once they had the chance, as is illustrated in Figure 1, which shows the evolution of both the Medicaid expansions and asset testing across states. States first had the option of both expanding Medicaid and dropping their asset tests in April 1987. The small slashed area shows the limited subset of states that chose to expand eligibility but not to drop their asset tests. Almost all states dropped their asset test as soon as they adopted the eligibility expansions, so that by the middle of 1989 fewer than 10 states still had asset tests.

Over the entire population, asset tests should lower savings, by the logic of the HSZ argument; but this effect might be expected to be small, to the extent that a large share of the population does not consider Medicaid to be a relevant option. Of more interest for our purposes is the interaction of asset tests with eligibility. In fact, the presence of an asset test could mitigate or exacerbate the savings impacts of the Medicaid eligibility. On the one hand, following the HSZ logic, in a world with an asset test individuals who are made eligible on income grounds but not on asset grounds may reduce their savings to qualify for the program. In this case the presence of an asset test will exacerbate the savings reduction (and consumption increase) from expanding Medicaid, since the newly eligible individuals must reduce their savings to qualify (on top of the precautionary effect discussed earlier).

${ }^{10}$ The value of a family's home is excluded from this asset test for AFDC, and the value of an automobile (up to $\$ 1500$ ) is excluded as well. (U.S. House of Representatives, 1994). The Medicaid expansions allowed families in states retaining asset tests to have assets holdings which were less than the SSI asset limit of $\$ 2000$, rather than the AFDC asset limit of $\$ 1000$. 
On the other hand, if an asset test is in place, newly eligible individuals with reasonably high savings may not consider this program a realistic option, so that the expansions will not affect their savings. Under this model, asset tests may mitigate the savings and consumption effects of expansions, since there is no precautionary savings effect or redistributive effect for newly eligible persons who are high savers (and who consider the program irrelevant). ${ }^{11}$ Finally, asset tests may have no effect, in that they are not binding or difficult to enforce. Thus, the net interactive effect of asset tests and eligibility is unclear. As a result, on net across these three effects, there is an ambiguous prediction for the effect of Medicaid eligibility on savings, but an unambiguous prediction that Medicaid eligibility should raise consumption.

\section{Related Empirical Work}

There is considerable evidence that precaution is an important motivation for savings. In the 1992 Survey of Consumer Finances, more households report precautionary saving as an important motive for their saving than any other reason (Kennickell and Starr-McCluer, 1994). Similar responses were reported in the 1983 and 1989 Surveys of Consumer Finances. In addition, a series of tests assessing the effects of variation in income risk across families on savings show that more risk leads to lower consumption and larger asset holdings. ${ }^{12}$ As Engen and Gruber (1995) discuss, however, these tests suffer from the problem that individual income risk may be the result of factors

\footnotetext{
${ }^{11}$ That is, in a world with no asset tests, the precautionary motive and redistributive effect would operate for all newly eligible individuals. In a world with asset tests, these effects may not operate for high wealth (but low income) eligibles who cannot possibly qualify for the program on wealth grounds. Note that this effect cannot offset the precautionary and redistributive effects; it just mitigates them to some extent.

${ }^{12}$ See, for example, Carroll and Samwick (1995); Dardanoni (1991); Dynan (1993); Guiso, Jappelli, and Terlizzese (1992); Kazarosian (1994); and the review in Browning and Lusardi (1996).
} 
that also determine savings, such as preferences for risk (as manifested through choice of occupation, for example). In addition, even if precaution is an important motivation for savings on average, one cannot naturally assume that social insurance programs "crowd out" this precautionary savings on the margin, since the savings disincentives embodied in social insurance programs may not be well understood by potential recipients.

There is previous empirical evidence on the effects of three different social insurance programs on savings. Kantor and Fishback (1996) explore the impact of the introduction of insurance against workplace injuries under the workers' compensation program, and find that there was a 25 percent reduction in the savings of working households, as well as a reduction in the purchase of private accident insurance. Engen and Gruber (1995) estimate the relationship between the generosity of the unemployment insurance program and wealth holdings, and find that increasing the generosity of unemployment insurance by one-half would lowers savings by 14 percent. Finally, there is a large literature on the effect of the Social Security program on savings: time series estimates of the effect of Social Security vary (Feldstein, 1974, 1982; Leimer and Lesnoy, 1982), while individual-level estimates indicate that each dollar of Social Security wealth is translated to 45 cents less savings (Diamond and Hausman, 1984).

These previous studies may not be predictive of the effect of Medicaid, however, for four reasons. First, although the benefit structure of each of these programs is progressive, none of the programs are means tested. Second, for the first two programs, under the empirically supported assumption that the costs of these social insurance benefits were fully shifted to workers' wages, ${ }^{13}$ there is no redistributive effects of the type described above. Third, none of these programs are

\footnotetext{
${ }^{13}$ For the case of workers compensation, see Fishback and Kantor (1995) and Gruber and Krueger (1991); for the case of unemployment insurance, see Anderson and Meyer (1995).
} 
asset tested. Finally, in these other cases, private insurance coverage is rare, perhaps due to widespread insurance market failures. ${ }^{14}$ But 71 percent of the non-elderly population is covered by private health insurance in the U.S. (Employee Benefits Research Institute, 1996). Thus, those individuals who remain uninsured may be a selected sample with little medical spending risk (or a low level of risk aversion), so that there is little precautionary savings to be crowded out among the uninsured.

The only paper of which we are aware that explicitly estimates the effects of asset tests is Powers (1996). She examines the effect of variations in asset testing for the AFDC program in the 1970 s on the savings of single female headed households. She finds a very strong effect of asset tests: each one dollar rise in the asset limit raises the savings of this population by 50 cents. But this study does not explore the role of program generosity, nor the interaction of generosity with asset testing.

Another closely related study is Starr-McCluer's (1996) analysis of health insurance and precautionary savings. She uses data from the 1989 Survey of Consumer Finances to examine the correlation between wealth holdings and insurance coverage. An important problem with this approach, of course, is that insurance status is an outcome of the same choice process the determines savings decisions. As a result, there could be a spurious positive correlation between insurance status and savings, for example because risk averse individuals have more of both. In fact, this is what Starr-McCluer finds: there is a positive effect of insurance coverage on wealth holdings. Her attempts to correct this problem, using as an instrument the share of employees in the area who work

${ }^{14}$ In Kantor and Fishback's (1996) sample, only 10 percent of individuals hold accident insurance. There is very little private unemployment insurance in the U.S.. Annuitization against mortality risk is very uncommon at the individual level, although many individuals are partially annuitized through firm pension plans. 
for large firms, are unsuccessful; even her corrected estimates show a positive relationship between health insurance and wealth. Thus, the effect of health insurance on precautionary savings remains an open question, which we can address with our plausibly more exogenous variation in Medicaid eligibility.

\section{Part II: Empirical Strategy}

Data

Our data come from two sources. The first is the Survey of Income and Program Participation (SIPP), covering the years 1984 to 1993. A new SIPP panel is introduced each calendar year, follows individuals for 24 to 32 months, and surveys approximately 15 to 20 thousand households. Because the panels overlap, households from as many as three different panels may be observed at a given point in time. Each panel interviews individuals in four-month intervals known as waves, where the respondent is asked retrospective information about the preceding four months.

The core questions are repeated at each interview and cover labor force activity, the types and amounts of income received during the four-month reference period, and participation status in various programs. From the core of the SIPP, we construct measures of family structure and the value of the Medicaid expansions to a household (discussed below).

The other major element of the SIPP is the various "topical modules" that are included during selected household visits. One of these supplements provides information on household wealth holdings. These questions are asked once or twice per panel, usually one year apart. This regular source of data on wealth holdings, collected for a large nationally representative sample over the period of the Medicaid expansions, makes the SIPP the best data source for our purposes. The wealth inventory is available for the fourth and seventh waves of 1984-86, the fourth wave of 1987 , 
1990 , and 1992, and the seventh wave of $1991 . .^{15}$

Our unit of observation in the SIPP sample is the household; since the wealth summary measures are collected only at the household level, we excluded households with more than one family in residence. Our sample consists of all households that were present in the SIPP at the point of the wealth interview, where the head is between the ages of 18 to 64 , and where there are no household members over the age of 64 , so that we can avoid complications arising from public insurance provided to those age 65 and over by the Medicare program. And we consider only household that live in a state that is uniquely identified by the SIPP, which groups some of the smaller states.

Wealth is measured as total household net worth, which is the sum of financial assets, home equity, vehicle equity, and business equity, net of unsecured debt holdings. Roughly one-quarter of the households in our data set have imputed wealth information, and the SIPP imputation methodology has been criticized by a number of commentators (Curtin, Juster, and Morgan, 1989; Hoynes, Hurd, and Chand, 1995). We therefore exclude imputed values for our analysis. Table 2 presents summary statistics of selected covariates of the head of household, the head's spouse (if present), and several family structure variables.

Our second data set is the Consumer Expenditure Survey (CEX). We use CEX data for the 1983-1993 period. The CEX collects information on a complete inventory of consumption items for a rotating sample of households each year. Households are interviewed for up to four quarters, providing information on household characteristics and consumption of different categories of goods. We use total non-durable, non-medical consumption as our dependent variable for part the CEX

${ }^{15}$ The first wealth supplement for 1985 was actually in the third interview. There was no survey in 1989 , and the 1988 survey did not contain a complete wealth inventory. 
analysis. ${ }^{16}$ Our CEX variables are averaged over all of the interviews for which the household is present. The CEX sample selection criteria are the same as for the SIPP; fewer states are identified in the CEX, however, due to confidentiality restrictions. The means of this data set are provided in Table 2 as well. The CEX and SIPP samples are very similar; the CEX sample is somewhat younger, less likely to be married, and has smaller families.

\section{Construction of Medicaid Variable}

Our key regressor is the generosity of the Medicaid program for a given household. We define generosity as the amount of expected medical spending for a given family which is made eligible for the Medicaid program, which we call "Medicaid eligible dollars." This measure of generosity varies across households for three reasons. The first is the legislative environment, which determines which types of individuals are eligible for Medicaid (i.e. age ranges of eligibility for children), and to what income level. The second is household structure, which determines how much medical spending will be made eligible for the family under a given legislative environment (i.e. covering an infant is more valuable than an older child). And the third is the cost of medical care in the area. This measure provides a natural parameterization of the effects of the Medicaid program on the household unit as a whole, which should determine savings decisions. ${ }^{17}$

\footnotetext{
${ }^{16} \mathrm{We}$ do not include housing durables expenditures because these may be a form of savings, rather than consumption.

${ }^{17}$ Making a dollar eligible for Medicaid is not the same as actually providing a dollar of insurance coverage, since in practice a large share of our sample will not take up the coverage for which they are eligible; see Currie and Gruber (1996a,b) and Cutler and Gruber (1996a) for a further discussion. For the purposes of our analysis, however, Medicaid eligibility is the more relevant concept. As emphasized by HSZ, it is the option of taking up social insurance which affects savings behavior, even among those who are not on the program at a point in time. By the same token, of course, it may be that even those ineligible for the program respond to the inherent savings disincentives, since they may become eligible. To the extent such a response exists, our estimates, which focus just on
} 
More precisely, we proceed as follows. First, for each child and each woman of childbearing age, we assign to them a likelihood of being Medicaid eligible. In theory, this could be assigned based on the family's actual income and other characteristics, following Medicaid rules. In practice, however, this runs into the problem that income is endogenous to the savings/consumption decision: income depends directly on savings through capital income receipt; and changes in private insurance coverage that result from becoming eligible may be reflected in wages (to the extent that the employer costs of insurance are shifted to wages) as well as in savings. As a result, we instead impute to each potentially eligible woman or child a likelihood of Medicaid receipt which is based only on purely exogenous characteristics that are correlated with their eligibility: the education of the household head (for children) or of the woman, the age of the child, state of residence, and year. The last three of these criteria are directly related to the dimensions of legislative variation in Medicaid policy. The first, education, serves as an exogenous proxy for income. We use four education categories: less than high school; high school graduate; some college; and college graduate.

Our imputation strategy is to measure the average eligibility rate in a given education/age/state/year cell, and then to assign that average eligibility to all persons in that cell. To determine eligibility, we use a detailed simulation model of Medicaid eligibility across all of the states and each year from 1983 to 1993 . As described in more detail in Currie and Gruber (1996a,b), this model includes the key features of each state's law and the federal eligibility rules over this period. In particular, we measure: the generosity of the state's AFDC program; the presence of each of the particular state options for covering non-AFDC groups (such as Ribicoff children); and the generosity of the Medicaid expansion taken up by the state at a given point in

the eligible population, will understate the savings effect of the Medicaid program. 
time..$^{18}$

We then use data from the March Current Population Survey (CPS) in each year to form average eligibility in each education/age/state cell, in several steps. ${ }^{19}$ First, we select from the CPS for each year a national random sample of children of each age, and of women of child-bearing age, in each of the four education categories. We then compute the eligibility of each person in this same sample, for each state's rules in that year. We then measure the average eligibility in each education/age/state cell to get a cell-specific eligibility measure, which we denote SIMELIG $_{i}$ By using a nationally representative sample, instead of a state-specific sample, we avoid any problems of correlations between state-specific demographic characteristics that determine eligibility and the savings/consumption behavior of residents of that state. In essence, this is a convenient parameterization of the rules of each state, as applied to the typical person in an education/age group cell. ${ }^{20}$ We then assign this average eligibility rate for each education/age/state/year cell to the SIPP

${ }^{18}$ Note that this model does not use asset information in determining eligibility. This would clearly be problematic in our context, since the point of our analysis is that assets are endogenous to program parameters. Whenever we refer to eligibility throughout the paper, we are referring to eligibility based on income and family structure only; we never impose asset tests in determining eligibility, due to this concern about endogeneity.

${ }^{19}$ We use the CPS, and not the SIPP or CEX, for this step of the analysis since the larger sample sizes guarantee a sufficient sample in each cell. Since we are simply imputing averages by cell, we can easily estimate the averages in the CPS and then carry them over to these other data sets. This also has the virtue that we use the same Medicaid eligibility construct in both the CEX and the SIPP.

${ }^{20}$ To illustrate, suppose that high school dropouts in Alabama have particularly low incomes (and therefore low savings), relative to high school dropouts elsewhere, and relative to other education groups in Alabama. If we used the actual sample of high school dropouts in Alabama, we would assign them a high fraction eligibile, based on their low incomes. We would find a spurious negative association between eligibility and savings, since they also have low savings. By using a nationally representative sample, we avoid this problem, since we are only using the laws of Alabama, and not the characteristics of its residents, to impute eligibility. 
and CEX data, to provide the first component of our Medicaid measure, imputed eligibility. ${ }^{21}$

The second determinant of Medicaid generosity is the expected medical spending that is covered by becoming Medicaid eligible. That is, covering an infant has a higher value to a family than covering a 9-year-old child, since infants have a much higher expected value of medical spending. We proxy the benefits of making a person of a given age and sex eligible for Medicaid by the mean spending of persons of that age and sex. ${ }^{22}$ We compute age/sex-specific spending on medical care from the 1987 National Medical Expenditure Survey (NMES) for 22 age/sex groups; these data are reported in the appendix to Cutler and Gruber (1996a). ${ }^{23}$

At the same time, there is enormous variation across places in the price of medical care which determine the value of Medicaid. We therefore normalize these national average spending figures by an index of relative state-specific medical costs. This index is formed by taking the Medicaid expenditure for one AFDC adult and two AFDC children in each state (except Arizona, which had a Medicaid demonstration project) for the years 1984 to 1993 , deflating to 1987 dollars,

\footnotetext{
${ }^{21}$ In practice, in fact, we carry out this exercise quarterly, to account for within-year variation in the timing of the expansions. We do this by assigning the same CPS sample to each quarter within a year. We then match to the precise quarterly timing of the SIPP and CEX samples.

${ }^{22}$ This approach ignores heterogeneity across households in their likelihood of needing medical care, which will be correlated with their value of Medicaid. But underlying health may be correlated with asset accumulation for other reasons, so we are reluctant to incorporate it in creating our value measure.

${ }^{23} \mathrm{We}$ also account for the complexity of Medicaid eligibility for women: very poor women will be eligible for all of their medical spending should they have a child, since they can join the AFDC program; while other women of somewhat higher incomes will be eligible under the Medicaid expansions for the expenses of pregnancy only. We therefore compute separately eligibility for AFDC and for other components of the program that cover pregnancy only. In computing total dollars eligible, we then multiply total spending for the women by her odds of being AFDC eligible, and expected pregnancy spending only by the odds of being eligible for other programs. To measure the value of the latter type of coverage, we multiply the total annual spending for women who had a child during the NMES survey year by the age-specific fertility rate for women in our sample.
} 
averaging over the ten years, and normalizing to one in the median state. The index varies from 0.70 in Mississippi to 1.38 in New York. ${ }^{24}$ We denote the area-specific, age-specific, spending measure as $\mathrm{SPEND}_{\mathrm{i}}{ }^{25}$

We combine these two components of generosity to form our key regressor, Medicaid eligible dollars:

$$
\operatorname{MED}_{\mathrm{j}}=\Sigma_{\mathrm{i}} \operatorname{SIMELIG}_{\mathrm{i}} \text { SPEND }_{1}
$$

where $\mathrm{MED}_{\mathrm{j}}$ is the expected dollars of medical spending that are made eligible for family $j$, which consists of individuals i. As Medicaid becomes more generous, either by increasing its income cutoffs or by covering more expensive family members, MED rises. We measure this value at each of the waves that precedes and includes the wealth wave in the SIPP, and at each quarterly interview in the CEX, and use the average in our regression. In this way, we smooth any noise in the measurement of family structure.

The time trend in Medicaid eligible dollars for our SIPP and CEX samples are shown in the first and fourth columns of Table 3. The pattern is very similar across the two datasets: Medicaid eligible dollars roughly double over the 1984 to 1993 period. Our CEX sample starts one year earlier, as noted above; and there is no SIPP data for the years 1989, 1990, and 1992, since there

\footnotetext{
${ }^{24}$ There is the one outlier state -- Alaska -- with a value of 1.77 .

${ }^{25}$ This normalization has two potential weaknesses. First, it is possible that the value of Medicaid is not determined by area-specific costs; it may be that the value is viewed in terms of services provided, not in terms of the costs of those services. But it seems more likely that individuals do consider the cost of services, since Medicaid is contrasted with either no insurance or private insurance, both of which will be more costly as medical costs are higher. Second, this measure captures not only price variation, but also variation in utilization of services by the Medicaid population. But utilization variation may also capture the quality of the Medicaid program, for example by representing the ease with which Medicaid patients can see providers in that states. In any case, our results are very similar if we do not use this deflator and instead simply use national average expenditures to form our measure.
} 
was no survey in 1988 or 1989 , and both the 1990 and 1991 wealth interviews took place during 1992.

Current eligibility for Medicaid is not the sole determinant of savings and consumption decisions, however: what is relevant is the entire future path of Medicaid eligibility. That is, consider two families who are living at the poverty line, in a state which has just expanded eligibility for children under age 6 to 133 percent of poverty. The first family has one child who is age 5 , and the second has one child who is age 1 . The effect on the savings and consumption of the second family will be much larger than those of the first family, since they face more years of reduced risk of medical expenditure.

We therefore also create a measure of expected future Medicaid eligible dollars. For projecting future eligibility, we assume a static expectations model; that is, we assume that individuals assess the eligibility of their family members if today's law remains in place into the infinite future. The family traces out the eligibility of a given family member as that member ages, within the constraints of today's eligibility of children of different ages (and pregnant women). ${ }^{26}$ The alternative would be a perfect foresight model, under which families anticipated future changes in eligibility laws; given the vagaries of the legislative process, we view our approach as more appropriate. We then discount future Medicaid eligibility dollars back to the present at a real interest rate of 6 percent.

Overall, Medicaid makes much more spending eligible in the future than it does today, as shown in Table 3. The amount of future Medicaid dollars eligible is roughly five times the amount

\footnotetext{
${ }^{26}$ That is, suppose that under current law in a given education/state/year category, 20 percent of 1 year-olds are covered, 10 percent of 2 to 6 year-olds are covered, and no 7+ year-olds are covered. The amount of future spending covered for a family with a 1 year-old is 10 percent of that child's spending for the next five years, and none of their spending after that.
} 
of current dollars eligible, although the time pattern is similar. Once again, the time patterns across the SIPP and CEX samples are very close. In our basic regression formulation, our Medicaid eligible dollars regressor is the sum of current dollars eligible (over the past year), and future dollars eligible, as shown in the third and sixth columns of Table 3.

\section{Regression Specification}

Our basic regression specification relates wealth holdings or consumption to Medicaid eligible dollars:

$$
\mathrm{A}_{\mathrm{j}}=\alpha+\beta_{1} \mathrm{MED}_{\mathrm{j}}+\beta_{2} \mathrm{EDCAT}_{\mathrm{j}}+\beta_{3} \mathrm{DEMOG}_{\mathrm{j}}+\beta_{4} \mathrm{X}_{\mathrm{j}}+\beta_{5} \delta_{\mathrm{s}}+\beta_{6} \tau_{\mathrm{t}}+\beta_{7} \delta_{\mathrm{s}}{ }^{*} \tau_{\mathrm{t}}+\epsilon_{\mathrm{j}}
$$

where $A_{j}$ is household net worth or consumption $\mathrm{MED}_{\mathrm{j}}$ is the sum of current and future Medicaid eligible dollars

EDCAT $_{j}$ is the education categories used to match Medicaid eligibility $D{ }^{2} \mathrm{OG}_{\mathrm{j}}$ is a set of controls for family demographic structure $X_{j}$ is an additional set of household-level covariates $\delta_{\mathrm{s}}$ is a full set of state dummies $\tau_{t}$ is a full set of time dummies

Our dependent variable for this analysis is a measure of household total net worth, or consumption in the CEX. Wealth holdings are very skewed, as we show in Table 4: 23 percent of our sample has net worth of less than or equal to zero; the median net worth in our sample is $\$ 11,171$, while the mean is $\$ 46,951 .{ }^{27}$ As a result, we use the log of wealth (or consumption) as our dependent variable. This raises the problem, however, that it may be inappropriate to simply estimate models based on the positive wealth observations: if Medicaid eligibility induces families with positive net worth to reduce their net worth to zero or below, then there may be a sample selection bias to such estimates. In fact, as we show below, there is a significant relationship

\footnotetext{
${ }^{27}$ Wealth and consumption are measured in real 1987 dollars, to match the timing of the NMES medical spending information used to create $\mathrm{MED}_{\mathrm{j}}$.
} 
between Medicaid eligibility and having positive wealth holdings. But we argue that the size of this relationship cannot explain much of the very large crowdout that we find in our log wealth models. Moreover, sample selection is not a problem for our consumption models, since there are no observations with zero consumption. Thus, the confirmation of our basic conclusions in the consumption data illustrates that our wealth results are not driven by selection.

Our key regressor, Medicaid eligible dollars, varies along four dimensions: education, state, year, and family structure (age and number of children; age of wife). Each of these dimensions may be independently correlated with savings decisions, however, leading to a potential bias to our estimates; for example, savings is very strongly positively correlated with education, wealthier states with higher savings may be the ones that expand their Medicaid program, and wealth has been documented to be strongly correlated with family structure. As a result, we include controls for each of these dimensions: dummies for each educational category ${ }^{28}$ dummies for each state; dummies for each year; and controls for total family size, the number of children of each age 0-18 in the family (number of 0 year-olds, number of 1 year-olds, etc.), and the number of women ages 15-18, $20-29,30-39$, and 40-44.

In addition, we are concerned that Medicaid policy may be correlated with other policies that affect savings across different states and years. We have addressed this to some extent by including state fixed effects in our specification. But even within states over time, there may be other correlated changes in social insurance programs that affect savings decisions. The most obvious candidate is changes in the AFDC program. Even after the Medicaid expansions, a key determinant of Medicaid eligibility for some groups (older children, non-pregnant women) is AFDC policy. And

\footnotetext{
${ }^{28}$ These include four dummies for the education of the head, and separate dummies for each of the age/education category of women who might be eligible for pregnancy coverage.
} 
AFDC may have independent effects on savings decisions, through the income effects of this cash transfer, and through the relatively low level of asset testing (at $\$ 1000$ ).

Fortunately, we can address this possibility directly in our regression specification, by including a full set of state*year interactions. AFDC policy only varies within states over time, so this will absorb any omitted correlation with AFDC generosity. But our model is identified even when these interactions are included because the "age notches" in Medicaid eligibility for children provide within state/year variation in eligibility; state expansions cover some age ranges of children and not others. That is, we control for general changes in state Medicaid (and possibly other program) policies over time, and identify our effects by the differential effects of these changes on groups for whom a given Medicaid eligibility change has relatively large or small effects.

Given this set of controls, the estimates of the effect of Medicaid are identified only through interactions of education, state, year, and family structure (but not through state*year interactions). It seems reasonable that these interactions are excluded from equation (2). Nevertheless, in a specification check below, we include some of these interactions in our estimated model to assess the robustness of our findings. We also include a number of other controls for the characteristics of the family: the head's age and its square, race, and marital status, and the education of the spouse.

The CEX regressions follow essentially the same specification, with consumption spending used as the dependent variable. Since consumption expenditures are non-zero for the entire sample, however, we simply estimate log spending regressions rather than using the two part specification described above. One potential concern with consumption spending is seasonality in consumption, since some families in our sample were not interviewed for all four quarters of the year. We therefore include in this regression, along with our set of year dummies, a full set of dummies for the months contained in the four sets of interviews; if the family was interviewed for four quarters, 
all of the month dummies will take on a value of one. We also include a set of dummy variables for the number of interviews for that family.

\section{Part III: Results}

\section{Basic SIPP Results}

Our basic SIPP results are presented in Table 5, which shows both the results from the probit specification of (1), and the log specification. We find a negative and highly significant effect of Medicaid in both specifications. In the second row of the table, we interpret the probit coefficient by presenting the effect of a $\$ 1000$ increase in Medicaid eligible dollars on the odds of holding positive assets; for each $\$ 1000$, there is a fall of $0.86 \%$ in the odds of having positive assets. Conditional on having positive net wealth, we find that for each $\$ 1000$ of Medicaid eligible dollars, wealth holdings fall by $2.91 \%$. These findings demonstrate that the Medicaid program has a sizeable effect on savings behavior, which is consistent with a precautionary savings response to reduced medical expenditure risk.

We can use these estimates to measure the net effect of the Medicaid program on asset holdings in 1993. Among those eligible for the Medicaid program, the average Medicaid eligible dollars is $\$ 5253 .^{29}$ Thus, for this population, there is a reduction in the odds of having positive net worth of $4.5 \%$, and a reduction in net worth holdings of $15.3 \%$. As an approximation, assume that those individuals who move from positive to zero net worth holdings would have otherwise had the median level of wealth among eligible positive wealth holders, and that they move to zero wealth. This implies that the total reduction in net worth holdings, accounting for individuals who reduce

\footnotetext{
${ }^{29}$ This number is much larger than the figure in Table 3 for 1993, since it is conditional on Medicaid eligibility.
} 
their wealth to zero, is $17.7 \%$. Moreover, under the same assumption, we find that the expansions from 1984 to 1993 lowered wealth holdings among this population by $8.2 \%$. These are fairly sizeable effects.

While this effect is large for the relevant population, however, it is trivial relative to overall asset holdings in our sample, due to the skewed nature of wealth holdings. The asset holdings of the eligible population in 1993 amounted to only 6.5 percent of the total asset holdings of our sample, despite the fact that this group is over $25 \%$ of our sample; this is because the mean net worth of eligibles is only one-quarter of the sample average. Thus, the $17.7 \%$ reduction in net worth holdings for this group translates to only a $1.2 \%$ reduction in aggregate net worth holdings.

As discussed earlier, one potential concern with these results is sample selection, since we are only using positive wealth observations in our log wealth models. If those moving from positive to zero savings were disproportionately high savers (above the mean for the sample), it would automatically induce a negative effect on savings in the remaining sample. But our small probit coefficients make this unlikely. In particular, given that we find a reduction in the odds of being a positive saver of only $4.5 \%$, we would require that those who move from being a positive saver to a non-positive saver had wealth holdings on average of over $\$ 43,500$ for selection to explain our findings. It seems highly unlikely that Medicaid could be causing a reduction in wealth from more than $\$ 43,500$ to zero, since for this population on average Medicaid eligible dollars average only $\$ 5253 . .^{30}$

\footnotetext{
${ }^{30}$ We have also tried to address this problem by estimating a standard "heckit" model (Heckman, 1979), using the first step probit to form a sample selection correction for the second stage conditional log regression. We have no excluded instruments that affect the decision to save and not the conditional level of savings, however, so that this model was identified by functional form assumptions only. In any case, the results from this estimation were nearly identical to what we show in Table 5, as the sample selection correction term was insignificant in the log wealth equation.
} 
The other potential concern about our model is the identification assumption that interactions of age of child/wife, education, state, and year, other than the included state*year interactions, do not affect savings decisions except through Medicaid policy. In Table 6, we explore the sensitivity of our findings to this assumption, by including in sequence some of the excluded second-order interactions: in the second row, we include age of child/wife*education group interactions; in the third row, we include age of child/wife*year interactions; and the fourth row, we include year*education group interactions. In no case does including these interactions significantly weaken our result; in the first two cases, our effects are actually strengthened. This demonstrates that our findings are not driven by excluded second-order interactions.

The covariates have their expected effects. Wealth rises with age, is higher for whites and lower for blacks (relative to other non-whites) and female heads, and rises with education and marital status. These effects are all highly significant.

The effects on the eligible population are very similar to the estimated effects of the previous literature on social insurance and savings. As noted above, Kantor and Fishback (1996) find that the introduction of workers' compensation insurance lowered the savings of working households by 25 percent, and Engen and Gruber (1995) estimate that increasing the generosity of unemployment insurance by one-half would lowers savings by 14 percent. Our finding of an $17.7 \%$ effect on the eligible population is in the range of both of these studies.

\section{Dollar Effects}

One natural question to ask about these results is: for every dollar of Medicaid eligibility, how much lower is wealth holdings? Evaluating our effects in dollar terms requires recognizing that the population that is affected by Medicaid is not representative of the full sample. In particular, 
given the skewed nature of wealth holdings, it is inappropriate to use the sample-wide summary statistics from Table 4. Moreover, summary statistics from our entire sample period incorporate the effects of the Medicaid expansions themselves, so that using them to evaluate our estimates would yield misleading results; for example, if asset holdings are lower due to Medicaid, then the base on which a percentage change is evaluated will be too low if the sample average is used.

We therefore evaluate our estimates in four steps. First, we use only the 1984 sample, before Medicaid had expanded eligibility. For this sample, we compute their actual eligibility for Medicaid, based on their family income and family structure (using the simulation program described earlier). We do this under both 1984 rules, and under 1993 rules, inflating family income to 1993 levels when applying these rules; that is, in the latter case we assess who would be eligible in 1984 under the 1993 program rules. Second, we compute Medicaid eligible dollars for these eligible families, under both 1984 and 1993 rules; eligible families are defined as families where any member is eligible. Third, we compute the weighted means of wealth only for the populations eligible in 1984 and 1993, where the weights are Medicaid eligible dollars. This weighted mean is both focused on the appropriate (eligible) population, and places more weight on the families who are most affected by Medicaid policy. Finally, we multiply our estimated effects per dollar of Medicaid eligibility by Medicaid eligible dollars in this population, which are much higher than those shown in Table 3, which include non-eligibles.

Using this approach, we find that the Medicaid program lowers asset holdings by between 38 and 43 cents for each dollar of eligibility. The first of these figures uses just the log wealth coefficient, while the second incorporates the probit effect as well, assuming that individuals who become non-positive savers would have otherwise had the median positive level of savings. This implies that, among the eligible population, Medicaid lowered wealth holdings by $\$ 1996$ to $\$ 2259$ 
in 1993, and that the expansions from 1984-1993 lowered wealth holdings by $\$ 928$ to $\$ 1051$.

\section{Asset Tests}

One potentially interesting feature of the Medicaid expansions is that they were associated with changes in asset testing, a central feature of the HSZ model. As we noted above, there is an ambiguous prediction for the interactive effect of asset testing with changes in Medicaid eligibility. We explore the role of asset tests in Table 7, by estimating models with a dummy for whether the state has an asset test, interacted with Medicaid dollars. There is no dummy for the presence of an asset test per se, since the asset test regime varies only by state and year, so that this is absorbed by our set of state*year dummies.

We find that there is in fact a negative interaction of eligibility with the presence of an asset test. For the probit, the interaction is significant; it indicates that having an asset test only raises the effect of a $\$ 1000$ increase in Medicaid eligible dollars from $0.83 \%$ to $1 \%$. For the $\log$ wealth regression, however, the interaction is highly significant and sizeable; indeed, it is actually larger than the main effect on Medicaid eligible dollars. This indicates that for each $\$ 1000$ in Medicaid eligible dollars, there is only a $2.04 \%$ reduction in assets if there is no asset test in place, but there is a 5.34\% reduction if there is an asset test in place. That is, having an asset test in place more than doubles the wealth reduction attributable to expanding Medicaid eligibility.

This pattern of effects should not be surprising: there is little reason to expect that an asset test at some positive level would change the odds of being a positive saver, but there should be an effect on the amount of savings that is done. Thus, our findings are consistent with the view that asset tests exacerbate the negative savings impact of the expansions by inducing wealth reductions in the population that is newly eligible on income grounds, but not on asset grounds. 


\section{Consumption Results}

As noted earlier, Medicaid eligibility is predicted to have two positive effects on consumption: reduced precautionary savings and redistribution. We explore the effect of Medicaid eligibility on measured consumption expenditures in Table 8. We show our basic specification, with the $\log$ of non-durable non-medical expenditures as the dependent variable. As above, these regressions include not only the covariates shown in the Table, but also a full set of controls for ages of children/wives, and full sets of dummies for states, years, and state*year interactions.

We find a highly significant positive effect of Medicaid eligibility on consumption, which is consistent with the negative effects on wealth holdings documented above. We estimate that for each $\$ 1000$ in eligibility, non-durable expenditures rises by 1.01 percent. For the eligible population in 1993, this estimate implies that their consumption was $5.2 \%$ higher as a result of Medicaid eligibility.

Once again, it is of interest to evaluate these effects in terms of dollars of increased consumption per dollar of Medicaid eligibility. Following the same procedure as above, we find that in 1993 Medicaid raised the consumption of eligible families by $\$ 663$. This effect is $29-33 \%$ as large as the effect on wealth holdings, which is consistent with the fact that the reduction in the stock of wealth is the cumulation of the flow effects of increased consumption. Comparing the precise magnitudes of the wealth and consumption effects is difficult, however, and requires an underlying model of the accumulation process. Nevertheless, these findings confirm the basic results from the wealth data: Medicaid raises consumption and lowers savings.

We explore the role of asset tests in these data in Table 9. Once again, we use as our key regressors Medicaid dollars, and an interaction of Medicaid dollars with a dummy for the presence of an asset test. And we once again find strong evidence with these consumption data for the 
proposition that Medicaid expansions reduce savings more when there is an asset test in place. The interaction coefficient is significant and roughly equal to the main effect on Medicaid dollars, indicating (as above) that the presence of an asset test doubles the consumption increase from expanded Medicaid eligibility. Taken together with the evidence for wealth holdings, our findings support the contention of HSZ that asset tests are an important determinant of savings (and consumption) behavior.

\section{Part IV: Conclusions}

Important theoretical advances in modeling precautionary savings over the past decade have raised the possibility that social insurance programs play an important role in determining both the level and distribution of asset holdings in the U.S. Our results confirm that the parameters of the Medicaid program are an important determinant of the savings behavior of low income households. We also confirm that households respond to asset testing upon becoming eligible for Medicaid; eligibility has a much larger negative effect on savings if there is an asset test in place. On net, we find that in 1993 the Medicaid program lowered the wealth holdings of eligible households by $17.7 \%$. We also find that the expansions of this program over the 1984-1993 period lowered wealth holdings by $8.2 \%$. Perhaps most importantly, we confirm that Medicaid lowers savings and raises consumption in two very different sources of data. These findings therefore offer strong empirical support to the contention of HSZ that social insurance programs contribute to the skewed distribution of assets in the U.S., by lowering the savings of eligible low income households.

At the same time, our findings offer some caution for the use of social insurance programs alone as an explanation for the level and distribution of U.S. wealth holdings. In aggregate, we estimate only a very small effect of Medicaid on asset holdings. Moreover, while our findings can 
explain some of the low asset holdings at the very bottom of the income distribution, there remains considerable skewness throughout the distribution (for example, among those families above $200 \%$ of the poverty line) which cannot be explained by this (or other) means tested programs. Of course, it is possible that means tested social insurance can affect savings of higher income households, as these families may eventually become poor enough to qualify. Future work in this area could usefully explore how the savings of non-eligibles responds to changes in the generosity of meanstested social insurance.

The normative implications of our findings are somewhat unclear. On the one hand, precautionary savings for medical expenditures is a particularly inefficient means of insurance. When risks are large and variable, market insurance is a much more effective means of smoothing consumption than is own savings. In this sense, our findings indicate increased efficiencies from expanded Medicaid eligibility which replaced self-insurance. On the other hand, there is enormous concern that savings is inefficiently low in the U.S. today. If there are other distortions in the economy which are causing our savings rate to be too low, then there could be large efficiency costs to reduced savings from social insurance programs.

We view our findings as confirming the positive contention that means-tested social insurance programs are an important determinant of savings behavior. An important priority for future research is to understand the normative implications of these findings, by exploring this tradeoff between replacing inefficient self-insurance and lowering savings rates. 


\section{References}

Abel, Andrew B., "Precautionary Saving and Accidental Bequests," American Economic Review 75 (September 1985): 777-791.

Anderson, Patricia M., and Bruce D. Meyer, "The Incidence of a Firm-Varying Payroll Tax: The Case of Unemployment Insurance". NBER Working Paper \#5201, August 1995.

Browning, Martin, and Annamaria Lusardi, "Household Saving: Micro Theories and Micro Facts," Journal of Economic Literature 34 (December 1996): 1797-1855.

Carroll, Christopher, and Andrew Samwick, "How Important is Precautionary Saving?" mimeo, Board of Governors of the Federal Reserve System, 1995.

Congressional Research Service. Costs and Effects of Extending Health Insurance Coverage. Washington, DC: U.S. Government Printing Office, 1988.

Currie, Janet, "Do Children of Immigrants Make Differential Use of Public Health Insurance?" NBER Working Paper \#5388, December 1995.

Currie, Janet, and Jonathan Gruber, "Saving Babies: The Efficacy and Cost of Recent Expansions of Medicaid Eligibility for Pregnant Women, "Journal of Political Economy, 104 (December 1996a): 1263-1296.

Currie, Janet, and Jonathan Gruber, "Health Insurance Eligibility, Utilization of Medical Care, and Child Health," Quarterly Journal of Economics, 111 (May 1996b): 431-466.

Curtin, Richard T., F. Thomas Juster, and James N. Morgan, "Survey Estimates of Wealth: An Assessment of Quality," in Robert E. Lipsey and Helen S. Tice, eds., The Measurement of Saving. Investment, and Wealth. Chicago: University of Chicago Press, 1989.

Cutler, David, and Jonathan Gruber, "Does Public Insurance Crowd Out Private Insurance?," Quarterly Journal of Economics, 111 (May 1996a): 391-430.

Cutler, David, and Jonathan Gruber, "The Effect of Medicaid Expansions on Public Insurance, Private Insurance, and Redistribution." American Economic Review 86 (May 1996b): 378-383.

Cutler, David, and Jonathan Gruber, "Medicaid and Private Insurance: Evidence and Implications," Health Affairs, 16 (January/February 1997): 194-200.

Dardanoni, Valentino, "Precautionary Savings Under Income Uncertainty: A Cross-Sectional Analysis," Applied Economics, 23 (January 1991): 153-160.

Deaton, Angus. Understanding Consumption, Oxford: Oxford University Press, 1992.

Diamond, Peter, and Jerry Hausman, "Individual Retirement and Savings Behavior," Journal of 
Public Economics 23 (February/March 1984): 81-114

Dubay, Lisa, and Gevenvieve Kenney, "Did the Medicaid Expansions for Pregnant Women Crowd Out Private Coverage?," Health Affairs', forthcoming 1996.

Dynan, Karen E., "How Prudent Are Consumers?," Journal of Political Economy, 101 (December 1993): 1104-1113.

Employee Benefits Research Institute (1996). "Sources of Health Insurance and Characteristics of the Uninsured". Issue Brief \#179, November.

Engen, Eric and Jonathan Gruber, "Unemployment Insurance and Precautionary Saving. NBER Working Paper \#5252, September 1995.

Feldstein, Martin, "Social Security, Induced Retirement, and Aggregate Capital Accumulation," Journal of Political Economy 82 (September/October 1974): 905-926.

Feldstein, Martin, "Social Security and Private Saving: Reply," Journal of Political Economy 90 (June 1982): 630-642.

Fishback, Price V., and Shawn Everett Kantor, "Did Workers Pay for the Passage of Workers' Compensation Laws?" Quarterly Journal of Economics 110 (August 1995):713-742.

Fisher, Malcolm, "Exploration in Savings Behavior," Oxford University Institute Statistics Bulletin 18 (August 1956): 201-277.

Friedman, Milton, A Theory of The Consumption Function. Princeton, N.J.: Princeton University Press (for NBER), 1957.

Gruber, Jonathan, "The Incidence of Mandated Maternity Benefits," American Economic Review, 84 (June 1994a): 622-641.

Gruber, Jonathan, "The Effect of Competitive Pressure on Charity: Hospital Responses to Price Shopping in California," Journal of Health Economics, 13 (July 1994b): 183-212.

Gruber, Jonathan, "Health Insurance for Poor Women and Children: Lessons from the Past Decade," forthcoming in James Poterba, ed. Tax Policy and the Economy 11. Cambridge, MA: MIT Press, 1996.

Gruber, Jonathan, and Alan Krueger, "The Incidence of Mandated Employer-Provided Insurance: Lessons from Workers' Compensation Insurance," Tax Policy and the Economy 5, David Bradford, ed., 1991. Cambridge, MA: MIT Press.

Gruber, Jonathan, and Brigitte C. Madrian, "Health Insurance and Job Mobility: The Effects of Public Policy on Job-Lock." Industrial and Labor Relations Review 48 (October 1994):86-102.

Guiso, Luigi, Tullio Jappelli, and Daniele Terlizzese, "Earnings Uncertainty and Precautionary 
Savings," Journal of Monetary Economics, 30 (1992): 307-337.

Hansen, Gary D., and Ayse Imrohoroglu, "The Role of Unemployment Insurance in an Economy with Liquidity Constraints and Moral Hazard," Journal of Political Economy 100 (February 1992): 118-142.

Heckman, James J., "Sample Selection Bias as a Specification Error," Econometrica, 47 (1979), 153-162.

Hoynes, Hilary, Michael Hurd, and Harish Chand, "Imputed Wealth, Subjective Survival Probabilities, and Social Security Wealth." Mimeo, NBER, May 1995.

Hubbard, R. Glenn and Kenneth L. Judd, "Social Security and Individual Welfare: Precautionary Saving, Liquidity Constraints, and the Payroll Tax," American Economic Review, 77 (September 1987): 630-646.

Hubbard, R. Glenn, Jonathan Skinner, and Stephen P. Zeldes, "Precautionary Saving and Social Insurance," Journal of Political Economy 103 (April 1995): 360-399.

Intergovernmental Health Policy Project, "Major Changes in State Medicaid and Indigent Care Programs." Debra J. Lipson, Rhona S. Fisher and Constance Thomas, Eds., The George Washington University, various editions.

Kantor, Shawn Everett, and Price V. Fishback, "Precautionary Saving, Insurance, and the Origins of Workers' Compensation." Journal of Political Economy 104 (April 1996): 419-442.

Kazarosian, Mark, "Precautionary Savings--A Panel Study," mimeo, 1994.

Kennickell, Arthur, and Martha Starr-McCluer, "Changes in Family Finances from 1989 to 1992: Evidence from the Survey of Consumer Finances," Federal Reserve Bulletin 80 (October 1994): 861-882.

Kotlikoff, Laurence J., "Health Expenditures and Precautionary Saving," in L. Kotlikoff, ed., What Determines Saving? Cambridge: MIT Press, 1988.

Kotlikoff, Laurence J., John Shoven, and Avia Spivak, "Annuity Markets, Savings, and the Capital Stock," in Z. Bodie, John Shoven, and David Wise, eds., Issues in Pension Economics, Chicago: University of Chicago Press, 1987.

Leimer, Dean, and Selig Lesnoy, "Social Security and Private Saving: New Time-Series Evidence," Journal of Political Economy 90 (June 1982): 606-629.

Powers, Elizabeth, "Does Means-Testing Welfare Discourage Saving? Evidence from the National Longitudinal Survey of Women," mimeo, Federal Reserve Bank of Cleveland, 1996.

Rask, Kimberly, and Kevin Rask, "Public Health Insurance and Moral Hazard," mimeo, Colgate University, 1995.

Sheiner, Louise, "Health Care Costs, Wages, and Aging: Assessing the Impact of Community 
Rating," Mimeo, Federal Reserve Board, 1996.

Sheshinski, Eytan, and Yoram Weiss, "Uncertainty and Optimal Social Security Systems, " Ouarterly Journal of Economics 96 (1981): 189-206.

Starr-McCluer, Martha, "Health Insurance and Precautionary Savings. " American Economic Review 86 (March 1996): 285-295.

U.S. House of Representatives. Background Material and Data on Programs within the Jurisdiction of the Committee on Ways and Means. Washington: Government Printing Office, 1994

Yelowitz, Aaron S., "The Medicaid Notch, Labor Supply, and Welfare Participation: Evidence from Eligibility Expansions." Quarterly Journal of Economics 110 (November 1995): 909-939. 


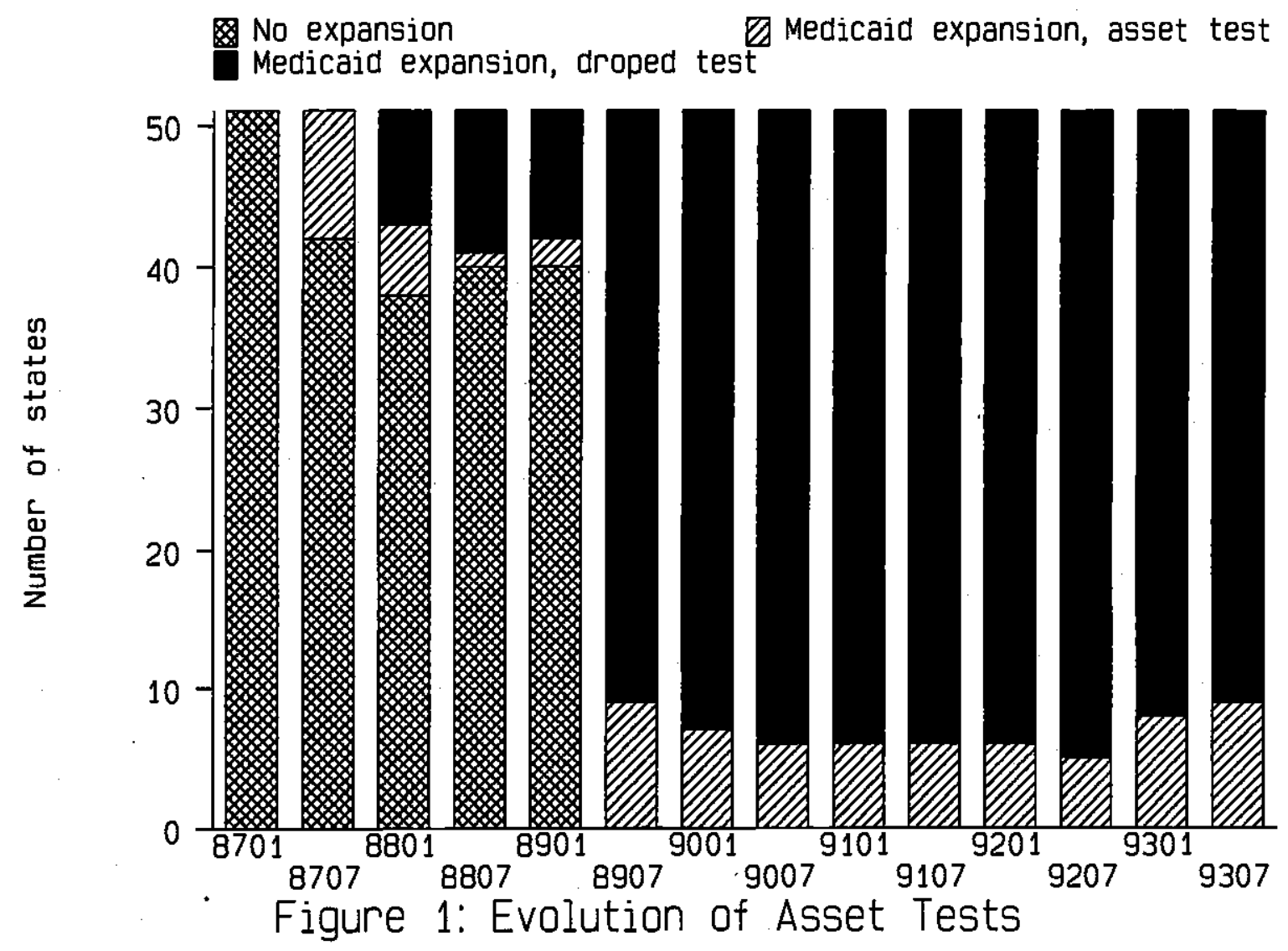


Table 1: State Medicaid Age and Income Eligibility Thresholds for Children.

\begin{tabular}{|c|c|c|c|c|c|c|c|c|}
\hline \multirow[b]{2}{*}{ State } & \multicolumn{2}{|c|}{ January 1988} & \multicolumn{2}{|c|}{ December 1989} & \multicolumn{2}{|c|}{ December 1991} & \multicolumn{2}{|c|}{ December 1993} \\
\hline & Age & Medicaid & Age & Medicaid & Age & Medicaid & Age & Medicaid \\
\hline Alabama & & & 1 & 185 & 8 & 133 & 10 & 133 \\
\hline Alaska & & & 2 & 100 & 8 & 133 & 10 & 133 \\
\hline Arizona & 1 & 100 & 2 & 100 & 8 & 140 & 12 & 140 \\
\hline Arkansas & 2 & 75 & 7 & 100 & 8 & 185 & 10 & 133 \\
\hline California & & & 5 & 185 & 8 & 185 & 10 & 200 \\
\hline Colorado & & & 1 & 75 & 8 & 133 & 10 & 133 \\
\hline Connecticut & 0.5 & 100 & 2.5 & 185 & 8 & 185 & 10 & 185 \\
\hline Delaware & 0.5 & 100 & 2.5 & 100 & 8 & 160 & 18 & 185 \\
\hline D.C. & 1 & 100 & 2 & 100 & 8 & 185 & 10 & 185 \\
\hline Florida & 1.5 & 100 & 5 & 100 & 8 & 150 & 10 & 185 \\
\hline Georgia & 0.5 & 100 & 3 & 100 & 8 & 133 & 18 & 185 \\
\hline Hawaii & & & 4 & 100 & 8 & 185 & 10 & 185 \\
\hline Idaho & & & 1 & 75 & 8 & 133 & 10 & 133 \\
\hline Illinois & & & 1 & 100 & 8 & 133 & 10 & 133 \\
\hline Indiana & & & 3 & 100 & 8 & 150 & 10 & 150 \\
\hline Iowa & 0.5 & 100 & 5.5 & 185 & 8 & 185 & 10 & 185 \\
\hline Kansas & & & 5 & 150 & 8 & 150 & 10 & 150 \\
\hline Kentucky & 1.5 & 100 & 2 & 125 & 8 & 185 & 10 & 185 \\
\hline Louisiana & & & 6 & 100 & 8 & 133 & 10 & 133 \\
\hline Maine & & & 5 & 185 & 8 & 185 & 18 & 185 \\
\hline Maryland & 0.5 & 100 & 6 & 185 & 8 & 185 & 10 & 185 \\
\hline Massachusetts & 0.5 & 100 & 5 & 185 & 8 & 185 & 10 & 200 \\
\hline Michigan & 1 & 100 & 3 & 185 & 8 & 185 & 10 & 185 \\
\hline Minnesota & & & 6 & 185 & 8 & 185 & 18 & 275 \\
\hline Mississippi & 1.5 & 100 & 5 & 185 & 8 & 185 & 10 & 185 \\
\hline Missouri & 0.5 & 100 & 3 & 100 & 8 & 133 & 18 & 185 \\
\hline Montana & & & 1 & 100 & 8 & 133 & 10 & 133 \\
\hline Nebraska & • & & 5 & 100 & 8 & 133 & 10 & 133 \\
\hline Nevada & & & 1 & 75 & 8 & 133 & 10 & 133 \\
\hline New Hamp. & & & 1 & 75 & 8 & 133 & 10 & 170 \\
\hline New Jersey & 1 & 100 & 2 & 100 & 8 & 185 & 10 & 300 \\
\hline New Mexico & 1 & 100 & 3 & 100 & 8 & 185 & 10 & 185 \\
\hline New York & & & 1 & 185 & 8 & 185 & 12 & 185 \\
\hline North Carolina & 1.5 & 100 & 7 & 100 & 8 & 185 & 10 & 185 \\
\hline North Dakota & & & 1 & 75 & 8 & 133 & 10 & 133 \\
\hline Ohio & & & 1 & 100 & 8 & 133 & 10 & 133 \\
\hline Oklahoma & 1 & 100 & 3 & 100 & 8 & 133 & 10 & 150 \\
\hline Oregon & 1.5 & 85 & 3 & 100 & 8 & 133 & 10 & 133 \\
\hline Pennsylvania & 1.5 & 100 & 6 & 100 & 8 & 133 & 10 & 185 \\
\hline Rhode Island & 1.5 & 100 &, 6 & 185 & 8 & 185 & 10 & 185 \\
\hline South Carolina & 1.5 & 100 & 6 & 185 & 8 & 185 & 10 & 185 \\
\hline South Dakota & & & 1 & 100 & 8 & 133 & 10 & 133 \\
\hline Tennessee & 1.5 & 100 & 6 & 100 & 8 & 185 & 10 & 185 \\
\hline Texas & & & 3 & 130 & 8 & 185 & 10 & 185 \\
\hline Utah & & & 1 & 100 & 8 & 133 & 10 & 133 \\
\hline Vermont & 1.5 & 100 & 6 & 225 & 8 & 225 & 17 & 225 \\
\hline Virginia & & & 1 & 100 & 8 & 133 & 18 & 133 \\
\hline Washington & 1.5 & 100 & 8 & 185 & 8 & 185 & 18 & 185 \\
\hline West Virginia & 0.5 & 100 & 6 & 150 & 8 & 150 & 18 & 150 \\
\hline Wisconsin & & & 1 & 130 & 8 & 155 & 10 & 155 \\
\hline Wyoming & & & 1 & 100 & 8 & 133 & 10 & 133 \\
\hline
\end{tabular}

Note: The age limit represents the oldest that a child could be (at a given point in time) and still be eligible. Medicaid represents the Medicaid income limit for an infant (the maximum for an older child is less).

Sources: Yelowitz (1995) and Intergovernmental Health Policy Project (various editions). 
Table 2: Characteristics of SIPP and CEX Samples

\begin{tabular}{lcr}
\hline \hline Variable & SIPP & CEX \\
\cline { 2 - 3 } Age of Head & 39.79 & 37.80 \\
Head is White & .84 & .83 \\
Head is Black & .12 & .12 \\
Head is Married & .60 & .53 \\
Head is HS Dropout & .20 & .17 \\
Head is HS Grad & .36 & .32 \\
Head has some College & .20 & .23 \\
Head is College Grad & .23 & .26 \\
Head is Female & .30 & .33 \\
Spouse is HS Dropout & .17 & .17 \\
(if present) & & .40 \\
Spouse is HS Grad & .43 & .20 \\
Spouse has some College & .20 & .22 \\
Spouse is College Grad & .18 & .86 \\
Number of Children $<$ 18 & .92 & \\
\hline \hline
\end{tabular}

Note: Based on authors' tabulations of SIPP and CEX data described in text. 
Table 3: Medicaid Eligible Dollars Over Time

\begin{tabular}{lcccccc}
\hline \hline & \multicolumn{3}{c}{ SIPP } & & \multicolumn{2}{c}{ CEX } \\
\cline { 2 - 6 } & Current & Future & Combined & Current & Future & Combined \\
\cline { 2 - 6 } 1983 & -- & - & -- & 198 & 1151 & 1349 \\
1984 & 193 & 1096 & 1290 & 195 & 1120 & 1315 \\
1985 & 220 & 1233 & 1454 & 219 & 1295 & 1515 \\
1986 & 235 & 1326 & 1561 & 228 & 1280 & 1508 \\
1987 & 249 & 1375 & 1625 & 246 & 1356 & 1603 \\
1988 & 241 & 1330 & 1571 & 243 & 1262 & 1505 \\
1989 & - & -- & - & 263 & 1341 & 1604 \\
1990 & -- & -- & -- & 327 & 1657 & 1985 \\
1991 & -- & 1805 & 2182 & 348 & 1919 & 2268 \\
1992 & 377 & -- & -- & 382 & 2194 & 2577 \\
1993 & -- & 2272 & 2674 & 378 & 2229 & 2608 \\
\hline \hline
\end{tabular}

Table 4: Summary Statistics on Wealth and Consumption

\begin{tabular}{lcc}
\hline \hline & Assets from SIPP & $\begin{array}{c}\text { Non-Durable } \\
\text { Expenditures }\end{array}$ \\
\cline { 2 - 3 } Mean & 46951 & 15573 \\
10th Percentile & 0 & 5569 \\
25th Percentile & 281 & 8711 \\
50th Percentile & 11171 & 13390 \\
75th Percentile & 56854 & 19688 \\
90th Percentile & 131027 & 27326 \\
\hline \hline
\end{tabular}

Notes: Figures in both tables in 1987 dollars. The SIPP sample did not contain observations from $1983,1989,1990$, or 1992 - thus these are missing from the table. 
Table 5: Medicaid and Asset Holdings

\begin{tabular}{|c|c|c|c|}
\hline & & Asset $>0$ & Log(Asset) \\
\hline $\begin{array}{l}\text { Combined Medicaid } \\
\text { Eligibility Dollars/1000 }\end{array}$ & $\cdot$ & $\begin{array}{l}-.0320 \\
(.0044)\end{array}$ & $\begin{array}{l}-.0291 \\
(.0063)\end{array}$ \\
\hline Marginal Effect of $\$ 1000$ & & -.0086 & - \\
\hline Head is Female & & $\begin{array}{l}-.1776 \\
(.0235)\end{array}$ & $\begin{array}{l}-.3061 \\
(.0296)\end{array}$ \\
\hline Head Age & & $\begin{array}{c}.0121 \\
(.0051)\end{array}$ & $\begin{array}{c}.0591 \\
(.0065)\end{array}$ \\
\hline Head Age $^{2} / 100$ & & $\begin{array}{l}-.0027 \\
(.0060)\end{array}$ & $\begin{array}{l}-.0151 \\
(.0076)\end{array}$ \\
\hline Head Black & & $\begin{array}{l}-.4315 \\
(.0437)\end{array}$ & $\begin{array}{l}-.5561 \\
(.0584)\end{array}$ \\
\hline Head White & & $\begin{array}{c}.1220 \\
(.0405)\end{array}$ & $\begin{array}{c}.3719 \\
(.0515)\end{array}$ \\
\hline Head HS Diploma & & $\begin{array}{l}.1630 \\
(.0224)\end{array}$ & $\begin{array}{c}.5421 \\
(.0285)\end{array}$ \\
\hline Head Some College & & $\begin{array}{l}.2058 \\
(.0262)\end{array}$ & $\begin{array}{c}.7545 \\
(.0329)\end{array}$ \\
\hline Head College Diploma & & $\begin{array}{l}.2394 \\
(.0278)\end{array}$ & $\begin{array}{l}1.1157 \\
(.0342)\end{array}$ \\
\hline Head Married & & $\begin{array}{c}.4146 \\
(.0342)\end{array}$ & $\begin{array}{l}.3784 \\
(.0488)\end{array}$ \\
\hline Spouse HS Diploma & & $\begin{array}{l}-.0330 \\
(.0336)\end{array}$ & $\begin{array}{c}.2334 \\
(.0476)\end{array}$ \\
\hline Spouse Some College & & $\begin{array}{l}-.0393 \\
(.0388)\end{array}$ & $\begin{array}{c}.3932 \\
(.0532)\end{array}$ \\
\hline Spouse College Diploma & ' & $\begin{array}{l}-.0647 \\
(.0424)\end{array}$ & $\begin{array}{c}.4100 \\
(.0557)\end{array}$ \\
\hline Mean & & .767 & 9.815 \\
\hline Number of obs & & 52,706 & 40,442 \\
\hline
\end{tabular}

Notes: Also included, but not shown, are STATE and YEAR fixed effects, STATE*YEAR interactions, dummies for number of family members, linear controls for age-gender group and age-education group, and a constant term. Column (1) is from a probit model and column (2) is from OLS. Standard errors in parentheses. 
Table 6: Coefficient on "Medicaid Eligible Dollars" from Alternative Specifications

\begin{tabular}{lcc}
\hline \hline & Asset $>0$ & Log(Asset) \\
\cline { 2 - 3 } Coefficient from Baseline Model & -.0320 & -.0291 \\
& $(.0044)$ & $(.0063)$ \\
Add AGE*EDUCATION interactions to & -.0389 & -.0328 \\
baseline model & $(.0056)$ & $(.0083)$ \\
Add AGE*YEAR interactions to baseline & -.0300 & -.0377 \\
model & $(.0050)$ & $(.0071)$ \\
Add YEAR*EDUCATION interactions to & -.0316 & -.0246 \\
baseline model & $(.0044)$ & $(.0064)$ \\
\hline Mean & .767 & 9.815 \\
Number of obs & 52,706 & 40,442 \\
\hline \hline
\end{tabular}

Notes: Also included, but not shown, are covariates presented in Table 5, STATE and YEAR fixed effects, STATE*YEAR interactions, dummies for number of family members, linear controls for age-gender group and age-education group, and a constant term. Column (1) is from a probit model and column (2) is from OLS. Standard errors in parentheses.

Table 7: Asset Test Interactions

\begin{tabular}{ccc}
\hline \hline & Asset $>0$ & Log(Asset) \\
\cline { 2 - 3 } Medicaid Dollars/ & -.0305 & -.0204 \\
1000 & $(.0045)$ & $(.0065)$ \\
& {$[-0.0082]$} & \\
Asset Test* & & \\
Medicaid Dollars/1000 & -.0062 & -.0330 \\
& $(.0047)$ & $(.0069)$ \\
\hline \hline
\end{tabular}

Notes: Regressions include set of covariates listed in Table 5 and note to that table. Column (1) is from a probit model and column (2) is from OLS. Standard errors in parentheses, marginal effect of probit in brackets. 
Table 8: Medicaid Eligibility and Consumption

\begin{tabular}{ll}
\hline \hline Eligibility Dollars & .0101 \\
& $(.0015)$ \\
Head is Female & -.0971 \\
& $(.0069)$ \\
Head Age & .0697 \\
Head Age $2 / 100$ & $.0015)$ \\
& -.0769 \\
Head Black & $(.0018)$ \\
& -.0856 \\
Head White & $(.0131)$ \\
& .1484 \\
Head HS Diploma & $(.0116)$ \\
& .2108 \\
Head Some College & $(.0080)$ \\
& .3027 \\
Head College Grad & $(.0088)$ \\
& .4935 \\
Head Married & $(.0093)$ \\
Spouse HS Diploma & .0413 \\
Spouse Some College & $(.0098)$ \\
& .0896 \\
Number of Observations & $(.0109)$ \\
\hline \hline & .1191 \\
& $(.0126)$ \\
& .2017 \\
& $(.0128)$ \\
\hline
\end{tabular}

Notes: Also included, but not shown, are STATE and YEAR fixed effects, STATE*YEAR interactions, dummies for number of family members, linear controls for age-gender group and age-education group, dummies for the months of the CEX interviews, and a constant term. Standard errors in parentheses. 
Table 9: Asset Test Interactions In The CEX

\begin{tabular}{lc}
\hline \hline Medicaid Dollars $/ 1000$ & .0053 \\
& $(.0019)$ \\
& \\
Asset Test* & .0064 \\
Medicaid Dollars $/ 1000$ & $(.0015)$ \\
\hline \hline
\end{tabular}

Notes: Standard errors in parentheses. Regressions include set of covariates listed in Table 8 and note to that table. 